Article

\title{
Preharvest Application of Oxalic Acid Improved Pomegranate Fruit Yield, Quality, and Bioactive Compounds at Harvest in a Concentration-Dependent Manner
}

\author{
María E. García-Pastor ${ }^{1}{ }^{\circledR}$, María J. Giménez ${ }^{1}$, Juan M. Valverde ${ }^{1}$, Fabián Guillén ${ }^{1}{ }^{\circledR}$, \\ Salvador Castillo ${ }^{1}$, Domingo Martínez-Romero ${ }^{1}$, María Serrano ${ }^{2}{ }^{\mathbb{D}}$, Daniel Valero ${ }^{1}{ }^{\mathbb{1}}$ and \\ Pedro J. Zapata ${ }^{1, *(D)}$ \\ 1 Department of Food Technology, EPSO, University Miguel Hernández, Ctra. Beniel km. 3.2, 03312 Alicante, \\ Spain; m.garciap@umh.es (M.E.G.-P.); maria.gimenezt@umh.es (M.J.G.); jm.valverde@umh.es (J.M.V.); \\ fabian.guillen@umh.es (F.G.); scastillo@umh.es (S.C.); dmromero@umh.es (D.M.-R.); \\ daniel.valero@umh.es (D.V.) \\ 2 Department of Applied Biology, EPSO, University Miguel Hernández, Ctra. Beniel km. 3.2, 03312 Alicante, \\ Spain; m.serrano@umh.es \\ * Correspondence: pedrojzapata@umh.es; Tel.: +34-966749789
}

Received: 20 August 2020; Accepted: 27 September 2020; Published: 6 October 2020

\begin{abstract}
The effects of oxalic acid (OA) applied in preharvest on pomegranate crop yield and quality properties have not yet been investigated. Pomegranate trees were treated with OA at 1,5, and $10 \mathrm{mM}$ along the developmental growth cycle during 2016, from full blossom until harvest, and the fruit diameter was recorded monthly. The yield was significantly higher in OA-treated pomegranate trees, the on-tree ripening process being promoted in a concentration-dependent manner. With respect to quality traits, OA at $10 \mathrm{mM}$ showed better results in terms of firmness, external color due to a red color enhancement, and respiration rate and sensory attributes. Then, a second-year experiment was performed with $\mathrm{OA}$ at $10 \mathrm{mM}$, and crop yield and fruit quality results were confirmed. In addition, an increase in glucose and total acidity, specifically malic and ascorbic acids, was observed in OA $10 \mathrm{mM}$-treated pomegranate fruit. Bioactive compounds were also higher in OA-treated fruit than control, the $10 \mathrm{mM}$ concentration being the most effective in increasing total phenolics, total anthocyanins, and total antioxidant activity. Overall, results suggest that OA applied at $10 \mathrm{mM}$ as preharvest treatment could be an effective tool to enhance pomegranate crop and quality and to improve the content of health-related compounds.
\end{abstract}

Keywords: anthocyanins; color; fruit size; phenolics; Punica granatum

\section{Introduction}

Pomegranate (Punica granatum L.) is a widely grown horticulture crop in many tropical and subtropical countries. The Romans received it from Carthage, hence the name of the genus Punica. During growth, pomegranate increased fresh weight continuously. The edible parts of pomegranate fruit represented $52 \%$ of the total weight, comprising $78 \%$ juice and $22 \%$ seeds [1]. 
Shulman et al. studied the growth curve of fruit and showed a single sigmoid curve [2]. Juice, total soluble solids, and anthocyanin content increased continuously during maturation while acidity decreased [3]. Pomegranate, being a non-climacteric fruit, should be picked when fully ripe, and fruit are ready for harvest in 5 to 6 months after the appearance of blossoms [4]. On the other hand, harvest maturity is also known to influence quality and could have a negative impact during storage, since early harvest may affect the development of the characteristic color, taste, and aroma of pomegranates, while late-harvested fruit exhibit a reduced shelf life [5]. Proper harvest of pomegranates also optimizes the health-promoting compounds in the fruit and juice. Its therapeutic properties have been used to treat different conditions (cardiovascular, neurological, diabetes, and cancer) for hundreds of years, and currently numerous in vitro and in vivo studies have shown the antioxidant, anti-inflammatory, and anti-tumoral properties of pomegranate [6]. During ripening of pomegranate, an accumulation of anthocyanins occurs in arils, these pigments being the responsible for the pink-red color. Total phenol concentration decreases rapidly in early development and more slowly as the fruit mature. The final concentration can range from 0.90 to $2.10 \mathrm{~g} \mathrm{~kg}^{-1}$, depending on cultivar and horticultural practices $[3,7,8]$. Pomegranate is considered as a highly nutritious fruit in which the edible parts of the fruit (arils) contain considerable amount of proteins, carbohydrates, minerals, sugars, vitamins, polysaccharides, and bioactive compounds such as anthocyanins and polyphenols [9].

Pomegranate fruit quality is determined by parameters such as fruit size, skin and aril color, sugar and acid content, and the presence of small and soft seeds. The landrace and best-known Spanish cultivar is "Mollar de Elche", which is characterized by presenting a high content of total soluble solids, low titratable acidity, small and soft seeds which can be easily eaten, and pleasant flavor [10]. These characteristics make it a cultivar highly appreciated by consumers in the markets. The external color is pale pink and the arils are pink-red, and this cultivar ripens in the months of October and November [11,12]. The Mollar de Elche cultivar has been safeguarded by a Protected Designation of Origin (PDO) since 2016 (R (UE) 2016/83) [13]. The external color of pomegranate fruit is one of the most important market requirements, but this cultivar present a lower pigmentation color in the husk [14] compared to other very important cultivars in economic terms, such as "Acco" or "Wonderful". Moreover, the early harvest is another key factor that influences the market prices [15]. Thus, increasing the harvest precocity of pomegranate fruit that reach the market with proper color could increase the economic profit for farmers.

Very few studies have been performed with preharvest treatments with naturally occurring compounds with the aim to increase fruit quality at the time of harvest, and even less with oxalic acid (OA). OA is a natural organic acid having many physiological functions mainly related to the induction of systemic resistance against fungal and viral diseases, through an increase in antioxidant enzymatic activities and phenolic compounds [16]. Recently, it has been classified as a generally recognized safe (GRAS) compound. The antioxidant capacity of this compound has been demonstrated, and its role as a natural antioxidant compound in plant systems has been proposed [17]. Moreover, postharvest OA application has shown benefits by retarding the postharvest ripening of climacteric fruits, but was also effective in non-climacteric fruits such as sweet cherry by extending the storability life during longer periods [18]. Specifically, in pomegranate fruit, the effect of OA treatments on pomegranate fruit quality has been assayed only in a previous paper, in which postharvest treatments, at 2, 4, and $6 \mathrm{mM}$, were performed before storage at $2{ }^{\circ} \mathrm{C}$, and results showed that $\mathrm{CI}$ symptoms were reduced and fruit quality properties maintained as compared with control fruits [19]. However, no previous reports are available in the literature regarding the effect of preharvest $\mathrm{OA}$ treatment on fruit growth and ripening and fruit quality properties at harvest and during storage, although a few studies have been published in other fruit species. 
As preharvest treatment, OA has been reported to increase yield and/or improve nutritional quality of sweet cherry [20], peach [21], kiwi [22], artichoke [23], strawberry [24], and plum [25], but its effect on pomegranate has not been investigated yet. Martínez-Esplá et al. treated "Sweet Heart" and "Sweet Late" sweet cherry cultivars with OA at 0.5, 1.0, and $2.0 \mathrm{mM}$ at 98, 112, and 126 days after full blossom (DAFB) by foliar spraying, and reported that fruit treated with $2 \mathrm{mM}$ OA showed the higher fruit size and antioxidant potential at harvest [20]. Similarly, $2 \mathrm{mM} \mathrm{OA}$ applied with a mechanical mist sprayer at 63,77, and 98 DAFB enhanced crop yield (kg per tree) and fruit weight of plum, although the on-tree ripening process was delayed [25]. However, no significant effect was found in the developmental process of artichoke plants sprayed with $2 \mathrm{mM} \mathrm{OA}$ solution at 45,24, and 3 days before harvesting, although the treatment lead to a higher number of first-class artichokes with higher hydrophilic total antioxidant activity at harvest and during cold storage [23]. On the other hand, different OA concentrations $(1,3$, and $5 \mathrm{mM})$ were applied on peach trees by preharvest spray at 15 days before harvest and results showed that OA, especially at $5 \mathrm{mM}$, enhanced fruit antioxidant capacity during storage [21]. Furthermore, Zhu et al. reported that the same concentration of OA applied on kiwifruit plants at 130,137, and 144 DAFB increased the postharvest quality and induced disease resistance of the fruit against Penicillium expansum [22]. Finally, field-grown strawberry plants were sprayed with 1 and $2 \mathrm{mM} \mathrm{OA}$ at the flowering stage to enhance plant growth parameters due to an enhanced concentration of the primary macronutrients [24]. These previous reports show that the effects of OA treatment depend on several factors, such as plant species, cultivar, applied concentration, or key stage of application during the growth developmental and ripening cycle. However, as mentioned above, its effects as a preharvest treatment in pomegranate fruit are unknown.

Thus, the main aim of the present study was to evaluate the effects of preharvest OA treatments at three concentrations $(1,5$, and $10 \mathrm{mM})$ to pomegranate trees on fruit size, crop yield (in terms of early harvest), respiration rate, and fruit quality characteristics, namely physico-chemical and sensory traits and individual sugars and organic acids content, as well as on bioactive compound content and antioxidant activity.

\section{Materials and Methods}

\subsection{Plant Material and Experimental Design}

The experiment was performed in a commercial orchard located in Elche, south of Alicante, Spain (UTMX: 694006.000 UTMY: 4234860.000) by using 10-year-old pomegranate trees of Mollar de Elche cultivar, planted at $6 \times 5 \mathrm{~m}$, and trained on a single-stem training system. In 2016, three OA concentrations were applied, 1, 5, and $10 \mathrm{mM}$, and the best results were obtained with the $10 \mathrm{mM}$ concentration. Thus, the $10 \mathrm{mM}$ OA concentration was used in 2017 in order to confirm the 2016 results. For both experiments, 2016 and 2017, a drip irrigation system with eight emitters per tree delivering $4 \mathrm{~L} \mathrm{~h}^{-1}$ was used, as follows: (i) Two watering cycles of $1 \mathrm{~h}$ per week in April, (ii) two watering cycles of $2 \mathrm{~h}$ per week in May, June, July, August, and September, (iii) and one watering cycle of $1 \mathrm{~h}$ in October. Soil was composed of sand (30\%), silt (34\%), and clay (36\%), and had a pH of 7.80. Climatic conditions in the crop field were a semi-arid Mediterranean climate, characterized by mean annual temperatures of 19.07 and $19.28^{\circ} \mathrm{C}$ for 2016 and 2017 , respectively, and maximum temperatures from June to September of 31.45 and $31.62{ }^{\circ} \mathrm{C}$ for 2016 and 2017, respectively. In addition, accumulated rainfall of 251.15 and $238.32 \mathrm{~mm}$ were registered for 2016 and 2017, respectively. In 2016, 3 blocks or replicates of five trees each $(n=15$ trees per treatment) were selected at random for the following treatments: Control and OA at 1,5, and $10 \mathrm{mM}$. Treatments were carried out by foliar spraying ( $3 \mathrm{~L}$ per tree) of freshly prepared OA (Sigma-Aldrich, Madrid, Spain) solutions, containing $1 \mathrm{~mL} \mathrm{~L}^{-1}$ Tween-20, along the developmental growth cycle during 2016 year in different key moments from full blossom until harvest. Specifically, four treatments were sprayed as follows: T1 (when fruit reached $30 \%$ of its final size), T2 (when fruit reached 50\% of its final size), T3 (1 month before harvesting), and T4 (4 days before harvesting) at 80, 110, 140, and 170 days after full blossom, respectively, which started in March (Julian days $=70$ and 
69, for 2016 and 2017, respectively). The last treatment was performed 4 days before harvesting in order to induce the systemic defense in the fruit by the treatments and to maintain this effect close to postharvest. Control trees were sprayed with distilled water containing $1 \mathrm{~mL} \mathrm{~L}^{-1}$ Tween-20. One week before T1 treatment, 10 fruit were labeled on the tree around the equatorial perimeter for each block or replicate of treatment and concentration ( $n=30$ fruit in total, 2 fruit per tree), in which fruit growth was followed by measuring cheek diameter $(\mathrm{mm})$ monthly. The following year, in the 2017 experiment, treatments were performed with OA at $10 \mathrm{mM}$, the best concentration selected based on the results of the previous year, and the control, which were applied following the same process described in the 2016 year, although using ten different trees in the same plot for each of the 3 blocks or replicates ( $n=30$ trees per treatment).

Fruit were harvested at the commercial ripening stage in accordance with commercial criteria based on parameters characteristic of this cultivar such as fruit size (diameter of $9.0 \mathrm{~cm}$, approximately, and fruit weight of $\approx 360 \mathrm{~g}$ ), husk color (pale pink), and total soluble solids (TSS) content $\left(\geq 15^{\circ}\right.$ Brix). In both experiments, fruit were harvested on two harvest dates due to the heterogeneous fruit ripening process occurred on tree. On both harvest dates, separated by 20 days, the total yield $\left(\mathrm{kg}\right.$ tree ${ }^{-1}$ and number of fruits tree ${ }^{-1}$ ) was determined for each tree and, with these data, the average fruit weight was calculated. In addition, since the first harvest is the most important for commercial profit, the yield of the first harvest ( $\mathrm{kg}$ tree ${ }^{-1}$, number of fruits tree ${ }^{-1}$, and fruit weight) was also performed.

In the 2016 experiment, from the fruit harvested from each tree, 2 fruit, homogenous in size and color and without visual defects, were taken at random and the fruit from the five trees of each block were mixed so that 10 fruit were taken for each block or replicate $(n=3)$ with a total of 30 fruit per treatment and concentration, and were transported to the laboratory immediately. However, in the 2017 experiment and in order to confirm the results, a greater number of fruits were transferred to the laboratory. Thus, 20 fruit of each block or replicate were harvested from the three blocks or replicates in order to obtain a homogeneous and randomized sample of 60 fruit for each treatment. In the same way as the 2016 experiment, the quality parameters were determined from 30 fruit of each treatment (10 fruit from 3 replicates). In addition, another 30 fruit of each treatment, previously selected, were used for descriptive sensory evaluation.

\subsection{Fruit Growth, Crop Yield, and Respiration Rate}

The evolution of fruit growth was recorded monthly in the labeled fruit from the T1 treatment by measuring the equatorial diameter in the 2016 experiment, and results were expressed in $\mathrm{mm}$. Two harvest dates were performed in both growing seasons. Total yield, expressed as $\mathrm{kg} \mathrm{tree}^{-1}$ and number of fruits tree ${ }^{-1}$, was measured and expressed as the result of both harvest dates. In addition, due to the economic profit of the fruit from the first harvest date, yield, expressed as $\mathrm{kg}$ tree $^{-1}$ and number of fruits tree ${ }^{-1}$, was determined. Then, fruit weight $(\mathrm{g})$ was calculated at two harvest dates. Results were expressed as the mean \pm SE.

To quantify fruit respiration rate at harvest, 5 fruit of each replicate were hermetically sealed for $60 \mathrm{~min}$ in a 3-L jar. Thus, there were 2 sealed jars of 5 fruit each for each replicate $(n=6$ jars per treatment and concentration). After that, one sample from the holder atmosphere of $1 \mathrm{~mL}$ was withdrawn with a syringe and injected in a gas chromatograph, as previously described by Sayyari et al. [26]. Respiration rate results were expressed as $\mathrm{mg} \mathrm{CO}_{2} \mathrm{~kg}^{-1} \mathrm{~h}^{-1}$ and was the mean $\pm \mathrm{SE}$. 
2.3. Physico-Chemical Quality Parameters: Color, Firmness, Total Soluble Solids, Titratable Acidity, Ripening Index, and Individual Sugars and Organic Acids

External color was determined using the CIE Lab system in a colorimeter (CRC200, Minolta Camera Co., Tokyo, Japan) along of the equatorial perimeter in six points of each of the ten fruit from each block or replicate. After recording $\mathrm{L}^{*}, \mathrm{a}^{*}$, and $\mathrm{b}^{*}$ parameters, color was expressed as hue angle $\left(\mathrm{h}^{\circ}\right)$, calculated as $\operatorname{arctg} \mathrm{b}^{*} / \mathrm{a}^{*}$. Fruit firmness was measured by using a TX-XT2i Texture Analyzer (Stable microsystems, Godalming, United Kingdom) and was determined individually in each of the ten fruit of each block or replicate. The percentage of deformation was a $3 \%$ of the fruit diameter. Results were expressed as $\mathrm{N} \mathrm{mm}^{-1}$, the relation between the applied force to achieve the deformation percentage and the distance traveled, and were the mean $\pm \mathrm{SE}$.

Pomegranate fruit were cut by the equatorial plane and peeled, and the arils of the ten fruit of each replicate were combined to obtain a homogeneous sample for each replicate. Total soluble solids (TSS) were measured in duplicate in the juice obtained from $30 \mathrm{~g}$ of pomegranate arils, by using a digital refractometer (Atago PR-101, Atago Co., Ltd., Tokyo, Japan) at $20^{\circ} \mathrm{C}$ and were expressed as $\mathrm{g} \mathrm{kg}^{-1}$ in fresh weight basis (FW). Titratable acidity (TA) was also determined in duplicate in each sample, by using $1 \mathrm{~mL}$ of diluted same juice (in $25 \mathrm{~mL}$ distilled $\mathrm{H}_{2} \mathrm{O}$ ), which was automatically titrated (785 DMP Titrino, Metrohm) with $0.1 \mathrm{~N} \mathrm{NaOH}$ up to $\mathrm{pH}$ 8.1, and the results were expressed as $\mathrm{g}$ malic acid equivalent $\mathrm{kg}^{-1}$ of FW basis. Ripening index (RI) was then calculated as the ratio of TSS/TA.

For sugars and organic acids quantification, $5 \mathrm{~g}$ of the aril sample of each replicate were extracted with $5 \mathrm{~mL}$ of water of $0.5 \%$ phosphoric acid and the supernatant was filtered through $0.45 \mu \mathrm{m}$ Millipore filter and injected into a HPLC system (Hewlett-Packard HPLC series 1100). In an isocratic system, the elution consisted of phosphoric acid at $0.1 \%$ running with a flow rate of $0.5 \mathrm{~mL} \mathrm{~min}^{-1}$ through a Supelco column (Supelcogel C-610H, $30 \mathrm{~cm}, 7.8 \mathrm{~mm}$, Supelco Park, Bellefonte, PA, USA). Organic acids were detected at $210 \mathrm{~nm}$ of absorbance and sugars by detector of refractive index and quantified by using standard curves of pure sugars and organic acids (Sigma-Aldrich, Germany). Results were expressed as $\mathrm{g} \mathrm{kg}^{-1} \mathrm{FW}$. Results were the mean $\pm \mathrm{SE}$ of three replicates. For the following determinations, the aril samples were stored at $-20^{\circ} \mathrm{C}$.

\subsection{Descriptive Sensory Evaluation}

A descriptive sensory analysis was performed in the 2017 experiment with trained panelists after a preconditioning of the harvested pomegranate fruit in cold chambers at $8{ }^{\circ} \mathrm{C}$ and at $85-90 \%$ of relative humidity. Ten panelists, aged between 25 and 55 years, 50\% female, from the Department of Agro-Food Technology of Miguel Hernández University of Elche (Orihuela, Alicante, Spain) were selected to participate in this study. Panelists received two preliminary orientation sessions of $60 \mathrm{~min}$ on sensory evaluation of pomegranate fruit in order to discuss the main attributes appreciated by consumers. Samples of 15 fruits per treatment were used to evaluate external fruit characteristics and $50 \mathrm{~g}$ of arils, obtained from a mixture of 15 fruits per treatment, and were served to each panelist at a controlled temperature of $20 \pm 2{ }^{\circ} \mathrm{C}$ in a testing room with a combination of natural and fluorescent light.

To quantify the intensity of the pomegranate fruit attributes, the panel used a numerical scale from 0 to 10; where 0 represented no perceptible intensity and 10 extremely strong intensity. The panel evaluated the following attributes: Brightness, color uniformity and intensity, firmness, and sweetness in the whole fruit, and sourness, bitterness, astringence, solubility in saliva (related to the fiber content of the seeds and, therefore, to their ease of eating), seed hardness, and overall liking in the arils. Overall liking was the result of the panelists satisfaction with respect to all the previous parameters. 


\subsection{Bioactive Compounds and Total Antioxidant Activity Quantification}

The bioactive compounds determined were the total phenolic and total anthocyanins content. Phenolic extraction was performed by homogenizing $5 \mathrm{~g}$ of the aril sample with $10 \mathrm{~mL}$ of methanol/water (8:2) containing $2 \mathrm{mM} \mathrm{NaF}$ by using a homogenizer (Ultraturrax, T18 basic, IKA, Berlin, Germany) for $30 \mathrm{~s}$. As previously described by Sayyari et al. [26], the extracts were centrifuged at 10,000 $\mathrm{g}$ for $10 \mathrm{~min}$ at $4{ }^{\circ} \mathrm{C}$ and the supernatant was used to quantify total phenolics compounds in duplicate by using the Folin-Ciocalteu reagent. The results were expressed as $g$ of gallic acid equivalent (GAE) per $\mathrm{kg}^{-1}$ of FW and were the mean $\pm \mathrm{SE}$ of three replicates.

To extract total anthocyanins, $5 \mathrm{~g}$ of arils were homogenized in $15 \mathrm{~mL}$ of methanol/formic acid/water $(25: 1: 24, v / v / v)$ and then, centrifuged at $10,000 \times g$ for $10 \mathrm{~min}$ at $4{ }^{\circ} \mathrm{C}$. The absorbance was measured in the supernatant at $520 \mathrm{~nm}$ and in duplicate for each extract according to García-Pastor et al. [27]. Total anthocyanin content (TAC) was expressed as g of cyanidin 3-O-glucoside equivalents per $\mathrm{kg}^{-1}$ of FW and were the mean $\pm \mathrm{SE}$ of three replicates.

Total antioxidant activity (TAA) was determined according to Sayyari et al. [26], which determines hydrophilic (H-TAA) and lipophilic (L-TAA) antioxidant activity in the same extraction. A calibration curve was performed with Trolox ((R)-(+)-6-hydroxy-2, 5, 7, 8-tetramethyl-croman-2-carboxylic acid) $(0-20 \mathrm{nmol})$ from Sigma-Aldrich (Madrid, Spain), and results were expressed as the sum of the antioxidant compounds present in both phases in $g$ of Trolox equivalent (TE) per $\mathrm{kg}^{-1}$ of FW and were the mean \pm SE of three replicates.

\subsection{Statistical Analysis}

Results were expressed as mean \pm SE of three replicates. Data for the analytical determinations of the 2016 experiment were subjected to analysis of variance (ANOVA) using treatment as the factor. Mean comparisons were performed using a multiple range test (Tukey's test) to examine if differences among treatments were significant at $p \leq 0.05, p \leq 0.01$, and $p \leq 0.001$. For data of the 2017 experiment, a Student's $t$-test was performed in order to detect significant differences between treatments at $p<0.05$. All analyses were performed with SPSS software package v. 17.0 for Windows.

\section{Results}

\subsection{Fruit Growth, Crop Yield, and Respiration Rate}

Pomegranate fruit growth was evaluated by recording the diameter $(\mathrm{mm})$ along the growth cycle in the 2016 season (Figure 1). As expected, a continuous increase in fruit weight was observed with a clear simple Sigmoid growth curve. Pomegranate trees were sprayed 4 times (from T1 to T4; Figure 1) along the fruit developmental cycle, and results showed that all concentrations of OA treatment stimulated fruit growth from the second application (T2; Figure 1), mainly in August, resulting in pomegranate fruit with higher size $(p \leq 0.05)$ at this developmental stage $(\approx 63 \mathrm{~mm}$ for control fruit and $66-68 \mathrm{~mm}$ for OA-treated pomegranate fruit), without significant differences $(p>0.05)$ among the concentrations of OA. Despite the fruit size being promoted by OA treatments at this key moment of the fruit developmental cycle, no significant differences $(p>0.05)$ were observed at harvest among treatments for this growth parameter (Figure 1). 


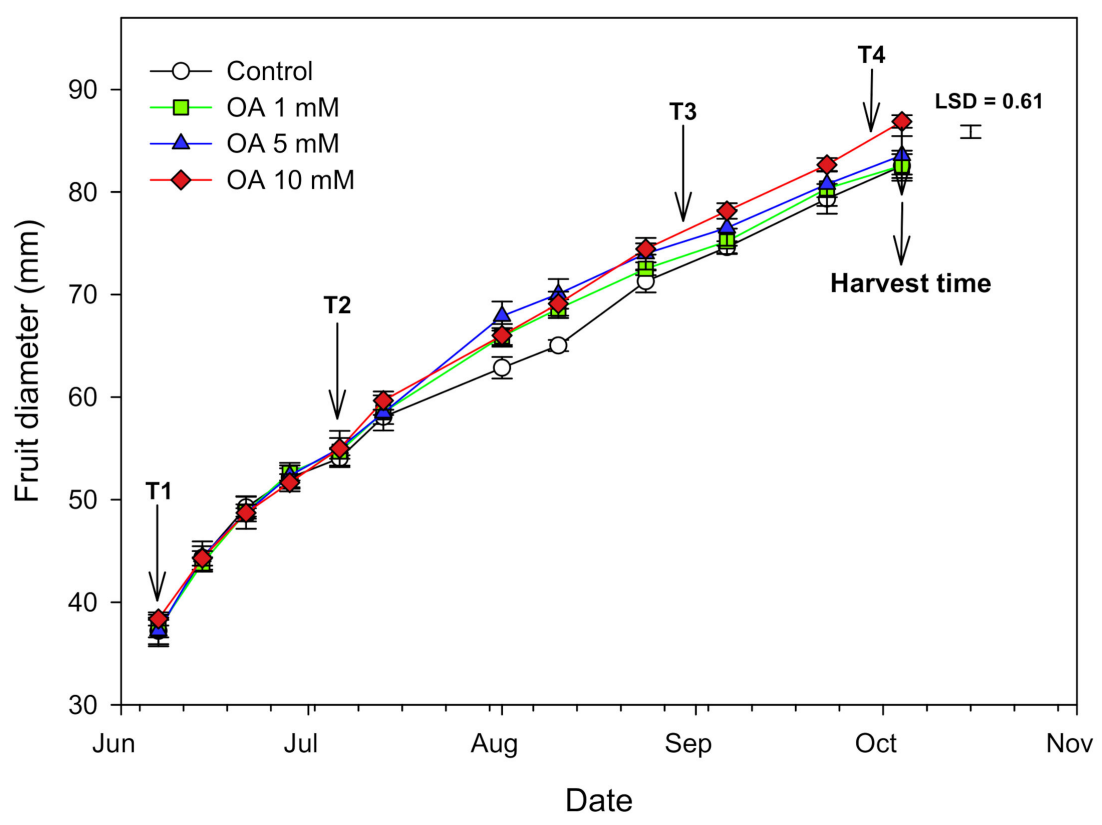

Figure 1. Pomegranate fruit diameter $(\mathrm{mm})$ during on-tree fruit development as affected by oxalic acid (OA) treatment at 1,5 , and $10 \mathrm{mM}$ in the 2016 experiment. Data are the mean $\pm \mathrm{SE} \mathrm{LSD}_{0.05}$ bar among treatments is shown. Arrows indicate the different key moments of treatments (T1, T2, T3, and T4) and the harvest time.

Two picking dates were performed for both years (2016 and 2017). For both, yield, expressed as kg tree $^{-1}$ and number of fruits tree ${ }^{-1}$, was significantly higher in OA-treated fruit than controls (Figure 2). Total yield of control fruit in 2016 was $37.75 \pm 3.28 \mathrm{~kg}^{-1} \mathrm{ree}^{-1}$, and significantly higher $(p \leq 0.05)$ in 1,5 , and $10 \mathrm{mM} \mathrm{OA} ; 47.88 \pm 5.17,46.04 \pm 8.06$, and $50.68 \pm 4.76 \mathrm{~kg}$ tree $^{-1}$, respectively. In the 2017 season, $10 \mathrm{mM} \mathrm{OA}$ as the concentration selected in the first season based on crop yield and fruit quality results was repeated and similar results on total yield were obtained compared with non-treated fruit. In addition, a significant increase on yield in the first harvest was observed by the OA treatment in a concentration-dependent manner $(p \leq 0.05)$, the higher concentration being the most effective, improving the kilograms of fruit tree ${ }^{-1}$ in terms of early harvest (Figure 2). The next year, similar results were obtained at the first harvest, where $10 \mathrm{mM}$ OA-treated trees produced $37.12 \pm 3.13 \mathrm{~kg}$ tree $^{-1}$ compared to $24.52 \pm 1.61 \mathrm{~kg}^{-1 r e e^{-1}}$ from controls. A similar trend was shown in relation to the number of fruits tree ${ }^{-1}$ (Figure 2), for which all treatments were effective $(p \leq 0.05)$ on increasing this crop parameter $(\approx 139,132$, and 138 fruit for 1,5 , and $10 \mathrm{mM} \mathrm{OA}$, respectively) compared to controls $(\approx 108$ fruit) in the first season. No significant differences were found between the different OA treatments $(p>0.05)$. However, the number of fruits tree ${ }^{-1}$ harvested in the first harvest date was significantly higher $(p \leq 0.05)$ only in the higher concentrations, OA at 5 and $10 \mathrm{mM}$, without differences $(p>0.05)$ between $1 \mathrm{mM}$ OA-treated trees and control trees. In the second season, $10 \mathrm{mM}$ OA significantly increased $(p<0.05)$ the number of fruit tree ${ }^{-1}$ of the total and first harvest production than non-treated trees by 20.68 and $82.06 \%$, respectively. For both seasons, fruit weight did not show significant differences $(p \geq 0.05)$ among treatments (Figure 2). 


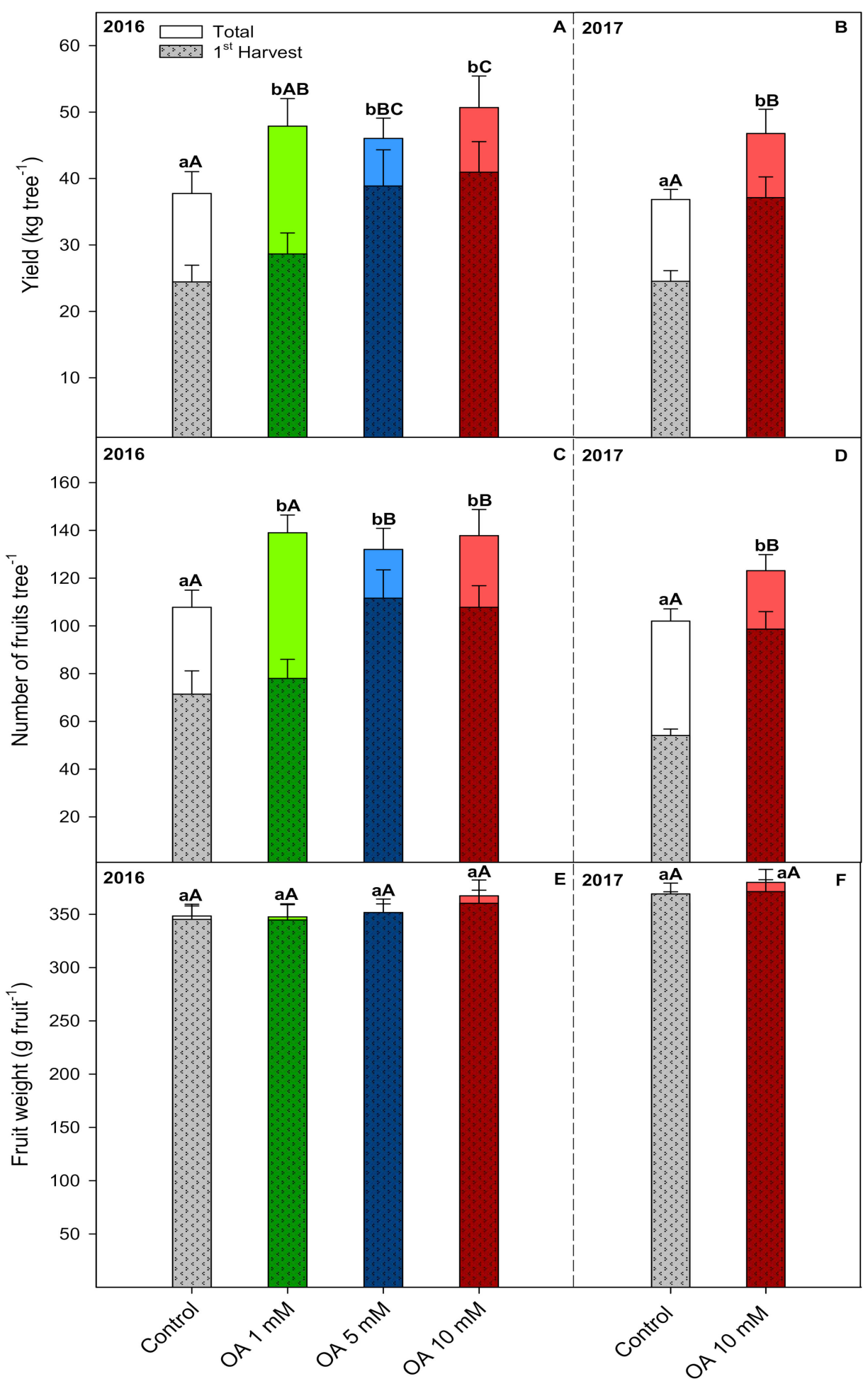

Figure 2. Effects of oxalic acid (OA) treatments on crop yield (kilograms per tree; $\mathbf{A}$ and $\mathbf{B}$ ), number of fruits per tree ( $\mathbf{C}$ and $\mathbf{D}$ ) and fruit weight (grams per fruit; $\mathbf{E}$ and $\mathbf{F}$ ) at the first harvest date (dotted bars) and at total harvest (open bars) for 2016 and 2017 years. Data are the mean \pm SE. Different lowercase letters show significant differences among treatments for total yield values and different capital letters show significant differences for results of the first harvest date at $p<0.05$. 
On the other hand, the respiration rate of pomegranate fruit was significantly lower $(p \leq 0.001)$ in fruit from 5 and $10 \mathrm{mM} \mathrm{OA}$-treated trees than in those from $1 \mathrm{mM} \mathrm{OA}$-treated trees and control trees at harvest (Table 1). In the 2017 experiment, the results were confirmed for this parameter (Table 1) and pomegranate fruit treated with $10 \mathrm{mM}$ OA showed a significantly lower $(p \leq 0.001)$ respiration rate than control ones (19.22 \pm 0.25 and $22.44 \pm 0.33 \mathrm{mg} \mathrm{CO}_{2} \mathrm{~kg}^{-1} \mathrm{~h}^{-1}$, respectively).

Table 1. Effects of preharvest oxalic acid (OA) treatments $(1,5$, and $10 \mathrm{mM})$ on pomegranate respiration rate and quality parameters; external color $\left(\mathrm{L}^{*}, \mathrm{a}^{*}\right.$ parameter and hue angle), firmness, total soluble solids (TSS), total acidity (TA), and ripening index (RI) in the first picking date in 2016 and 2017 experiments. Data are the mean $\pm \mathrm{SE}$.

\begin{tabular}{|c|c|c|c|c|c|}
\hline \multicolumn{6}{|c|}{2016 Experiment } \\
\hline Parameter & ANOVA $^{\dagger}$ & Control & OA $1 \mathrm{mM}$ & OA $5 \mathrm{mM}$ & OA $10 \mathrm{mM}$ \\
\hline $\begin{array}{l}\text { Respiration rate } \\
\left(\mathrm{mg} \mathrm{CO}_{2} \mathrm{~kg}^{-1} \mathrm{~h}^{-1}\right)\end{array}$ & $* * *$ & $23.99 \pm 0.32 b B$ & $22.49 \pm 0.24 b$ & $19.35 \pm 0.47 a$ & $20.36 \pm 0.80 \mathrm{aA}$ \\
\hline $\mathrm{L}^{*}$ & $* *$ & $64.22 \pm 0.76 \mathrm{bA}$ & $62.05 \pm 0.87 \mathrm{ab}$ & $60.03 \pm 0.95 a$ & $59.80 \pm 0.92 a A$ \\
\hline External $\quad a^{*}$ & * & $32.23 \pm 1.16 \mathrm{aB}$ & $34.57 \pm 1.32 \mathrm{ab}$ & $36.56 \pm 1.18 \mathrm{ab}$ & $37.85 \pm 1.24 \mathrm{bB}$ \\
\hline color $\quad h^{\circ}$ & * & $44.20 \pm 1.52 \mathrm{bA}$ & $41.66 \pm 1.62 \mathrm{ab}$ & $39.38 \pm 1.45 \mathrm{ab}$ & $38.59 \pm 1.41 \mathrm{aA}$ \\
\hline Firmness $\left(\mathrm{N} \mathrm{mm}^{-1}\right)$ & $*$ & $16.79 \pm 0.74 \mathrm{aA}$ & $16.56 \pm 0.44 a$ & $17.26 \pm 0.32 \mathrm{ab}$ & $18.81 \pm 0.37 \mathrm{bA}$ \\
\hline TSS $\left(\mathrm{g} \mathrm{kg}^{-1}\right)$ & $* * *$ & $168.40 \pm 0.50 \mathrm{aA}$ & $170.40 \pm 0.50 a$ & $169.70 \pm 0.40 a$ & $181.30 \pm 0.80 \mathrm{bA}$ \\
\hline $\mathrm{TA}\left(\mathrm{g} \mathrm{kg}^{-1}\right)$ & $* * *$ & $4.20 \pm 0.10 \mathrm{aA}$ & $4.60 \pm 0.10 b c$ & $4.40 \pm 0.10 \mathrm{ab}$ & $4.80 \pm 0.10 \mathrm{cA}$ \\
\hline RI & NS & $40.26 \pm 1.22 \mathrm{~A}$ & $37.06 \pm 1.01$ & $38.48 \pm 1.04$ & $37.73 \pm 1.21 \mathrm{~A}$ \\
\hline \multicolumn{6}{|c|}{2017 Experiment } \\
\hline Parameter & $\begin{array}{c}\text { Student's } \\
t \text {-Test }\end{array}$ & Control & OA $1 \mathrm{mM}$ & OA $5 \mathrm{mM}$ & OA $10 \mathrm{mM}$ \\
\hline $\begin{array}{c}\text { Respiration rate } \\
\left(\mathrm{mg} \mathrm{CO}_{2} \mathrm{~kg}^{-1} \mathrm{~h}^{-1}\right)\end{array}$ & * & $22.44 \pm 0.33 \mathrm{~A}$ & - & - & $19.22 \pm 0.25 \mathrm{~A}$ \\
\hline \multirow{3}{*}{$\begin{array}{ll}\text { External } & \mathrm{A}^{*} \\
\text { color } & \mathrm{h}^{\circ}\end{array}$} & * & $73.29 \pm 0.95 B$ & - & - & $67.54 \pm 0.89 B$ \\
\hline & * & $15.48 \pm 1.31 \mathrm{~A}$ & - & - & $25.44 \pm 1.80 \mathrm{~A}$ \\
\hline & * & $67.60 \pm 1.85 \mathrm{~B}$ & - & - & $55.45 \pm 2.27 \mathrm{~B}$ \\
\hline Firmness $\left(\mathrm{N} \mathrm{mm}^{-1}\right)$ & * & $25.69 \pm 0.62 B$ & - & - & $27.71 \pm 0.76 \mathrm{~B}$ \\
\hline TSS $\left(\mathrm{g} \mathrm{kg}^{-1}\right)$ & * & $169.10 \pm 0.50 \mathrm{~A}$ & - & - & $180.80 \pm 0.70 \mathrm{~A}$ \\
\hline $\mathrm{TA}\left(\mathrm{g} \mathrm{kg}^{-1}\right)$ & $*$ & $4.10 \pm 0.10 \mathrm{~A}$ & - & - & $5.00 \pm 0.10 \mathrm{~A}$ \\
\hline RI & NS & $40.83 \pm 1.51 \mathrm{~A}$ & - & - & $37.11 \pm 1.37 \mathrm{~A}$ \\
\hline
\end{tabular}

3.2. Physico-Chemical Quality Parameters: Color, Firmness, Total Soluble Solids, Titratable Acidity, Ripening Index, Individual Sugars and Organic Acids, and Sensory Evaluation

With respect to external color, significant differences were observed on luminosity or $\mathrm{L}^{*}(p \leq 0.01)$, $\mathrm{a}^{*}$ color parameter $(p \leq 0.05)$ and hue angle or $\mathrm{h}^{\circ}(p \leq 0.05)$ among treatments (Table 1$)$. In a concentration-dependent manner, lower values of luminosity and higher $\mathrm{a}^{*}$ values were measured at harvest in fruit from OA-treated trees. Hue angle of pomegranate husk was lower in fruit from $1(41.66 \pm 1.62), 5(39.38 \pm 1.45)$, and 10 (38.59 \pm 1.41$)$ mM OA-treated trees than in controls $(44.20 \pm 1.52)$, showing a deeper red external color of OA-treated fruit, especially for the $10 \mathrm{mM}$ concentration in which the lowest hue value was obtained, as can be seen in Figure S1. These differences were significantly increased $(p<0.05)$ between $10 \mathrm{mM} \mathrm{OA-treated} \mathrm{fruit} \mathrm{and} \mathrm{the} \mathrm{control} \mathrm{in} \mathrm{the} 2017$ season for all the color parameters mentioned above (Table 1). 
Fruit firmness at harvest was significantly $(p \leq 0.05)$ increased by $10 \mathrm{mM}$ OA treatment (Table 1 ) with fruit treated with $10 \mathrm{mM}$ OA having 2 units greater firmness in both seasons. Figure 3 shows the sensory profiles of 10-mM-treated and non-treated pomegranate fruit and the list of the main sensory attributes used in the description of the fruit. Significant differences were found in 8 out the total 12 sensory attributes evaluated. This profile was characterized by high values in appearance and firmness attributes from $10 \mathrm{mM} \mathrm{OA-treated} \mathrm{pomegranate} \mathrm{fruit} \mathrm{such} \mathrm{as} \mathrm{size} \mathrm{(8.0),} \mathrm{brightness} \mathrm{(8.0),} \mathrm{color}$ uniformity (7.0), color intensity (9.0), and firmness (7.0), which are consistent with the physico-chemical values obtained. However, trained panelists detected that fruit size was higher in $10 \mathrm{mM}$ OA-treated fruit compared to untreated fruit, although no significant differences were observed for this parameter at harvest in 2017 when fruit weight was calculated as the total fruit production by tree $(\mathrm{kg})$ and number of harvested fruit per tree.

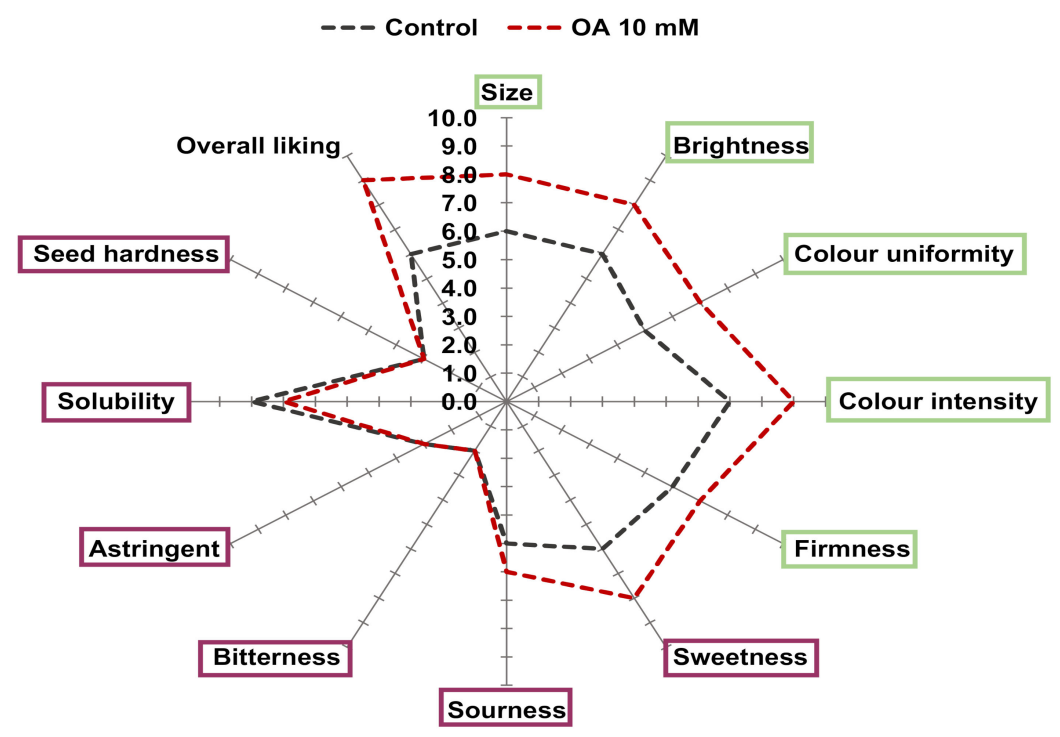

Figure 3. Descriptive sensory analysis of oxalic acid (OA) 10-mM-treated and non-treated (control) pomegranate fruit in the 2017 experiment. Size, brightness, color uniformity and intensity, firmness, sweetness, sourness, bitterness, astringence, solubility, seed hardness, and overall liking were evaluated by trained panelists in a hedonic scale from 0 to 10 points. Parameters highlighted by a green and purple box were evaluated in the whole fruit and in the arils, respectively.

Table 1 shows that TSS at harvest were $168.40 \pm 0.50 \mathrm{~g} \mathrm{~kg}^{-1}$ in arils from control, and significantly higher $(p \leq 0.001)$ in $10 \mathrm{mM}$ OA-treated ones, with $181.30 \pm 0.80 \mathrm{~g} \mathrm{~kg}^{-1}$ in the 2016 experiment, while no significant effects were observed for OA treatments at 1 and $5 \mathrm{mM}$. This significant difference $(p<0.05)$ between $10 \mathrm{mM}$ OA and control arils were confirmed in the 2017 experiment (Table 1). Similarly, TA showed significant differences, especially for $10 \mathrm{mM} \mathrm{OA} \mathrm{concentration}(p \leq 0.001$; Table 1$)$, whereas $1 \mathrm{mM}$ OA concentration also increased its total acidity, with an increase for both concentrations of 1.14- and 1.10-fold higher than the control fruit. In the second year, arils from $10 \mathrm{mM}$ OA-treated fruit showed 1.22-fold higher values of total acidity than arils from non-treated pomegranate fruit $(p<0.05$; Table 1). However, the RI was not affected by OA treatments $(p \geq 0.05)$, with values ranging between 37 and 41 for both years (Table 1). Figure 3 showed that sweetness (8.0) and sourness (6.0) were higher in $10 \mathrm{mM}$ OA-treated fruit. Besides, overall linking (9.0) was also found higher in OA-treated pomegranate fruit. However, no significant differences were found between treatments related to bitterness, astringence, solubility in saliva, or seed hardness attributes. On the other hand, significant differences were observed for respiration rate, external color, and firmness, among years (Table 1).

Fructose was the major sugar in pomegranate arils, followed by glucose, the last one being significantly $(p \leq 0.05)$ increased by $10 \mathrm{mM} \mathrm{OA}$ treatment, reaching $69.04 \pm 0.71 \mathrm{~g} \mathrm{~kg}^{-1}$, while sucrose was found at very low concentration without significant differences $(p>0.05)$ attributed to treatments 
(Table 2). Oxalic, malic, and ascorbic organic acids were also significantly increased $(p \leq 0.05 ; p \leq 0.01$; $p \leq 0.01$, respectively) by $10 \mathrm{mM} \mathrm{OA}$ treatment, the highest increase being found in the major organic acid, malic acid. Moreover, ascorbic acid increased 1.17-fold higher in $10 \mathrm{mM}$ OA-treated pomegranate than in the control fruit (Table 2).

Table 2. Effects of preharvest oxalic acid (OA) treatments $(1,5$, and $10 \mathrm{mM})$ on individual sugar and organic acid concentration $\left(\mathrm{g} \mathrm{kg}^{-1}\right)$ in the first picking date in 2016 experiment. Data are the mean \pm SE.

\begin{tabular}{ccccccc}
\hline \multicolumn{2}{c}{ Parameter } & ANOVA $^{+}$ & Control & OA 1 mM & OA 5 mM & OA 10 mM \\
\hline \multirow{3}{*}{ Individual } & Sucrose & NS & $0.58 \pm 0.01$ & $0.54 \pm 0.02$ & $0.59 \pm 0.02$ & $0.62 \pm 0.01$ \\
sugars & Glucose & $*$ & $61.04 \pm 0.59 \mathrm{a}$ & $64.71 \pm 1.71 \mathrm{ab}$ & $64.04 \pm 1.69 \mathrm{ab}$ & $69.04 \pm 0.71 \mathrm{~b}$ \\
& Fructose & NS & $106.48 \pm 2.01$ & $108.53 \pm 1.60$ & $107.28 \pm 2.42$ & $115.51 \pm 2.21$ \\
& Oxalic acid & $*$ & $0.14 \pm 0.01 \mathrm{a}$ & $0.17 \pm 0.01 \mathrm{ab}$ & $0.18 \pm 0.01 \mathrm{ab}$ & $0.21 \pm 0.01 \mathrm{~b}$ \\
Organic & Citric acid & NS & $0.67 \pm 0.05$ & $0.66 \pm 0.05$ & $0.65 \pm 0.02$ & $0.75 \pm 0.06$ \\
acids & Malic acid & $* *$ & $3.06 \pm 0.10 \mathrm{a}$ & $3.39 \pm 0.05 \mathrm{a}$ & $3.28 \pm 0.11 \mathrm{a}$ & $3.93 \pm 0.05 \mathrm{~b}$ \\
& Ascorbic acid & $* *$ & $0.47 \pm 0.02 \mathrm{a}$ & $0.50 \pm 0.01 \mathrm{ab}$ & $0.51 \pm 0.01 \mathrm{ab}$ & $0.55 \pm 0.01 \mathrm{~b}$ \\
& Succinic acid & NS & $1.45 \pm 0.19$ & $1.59 \pm 0.15$ & $1.50 \pm 0.06$ & $1.94 \pm 0.04$ \\
\hline
\end{tabular}

${ }^{\dagger} \mathrm{NS}=$ not significant; ${ }^{*}, * *$, and ${ }^{* * *}$ significant at $p \leq 0.05,0.01$, and 0.001 , respectively. Values (mean of three replicates) followed by different letters, within the same row, show significantly differences $(p<0.05)$ among treatments, according to the Tukey's multiple range test.

\subsection{Bioactive Compounds and Total Antioxidant Activity}

In the 2016 experiment, OA treatment at 5 and $10 \mathrm{mM}$ led to arils with increased concentrations of total phenolics and total anthocyanins compared to control fruit at harvest time $(p \leq 0.001)$. For the total anthocyanin concentration, values at harvest were significantly higher $(p \leq 0.001)$ in arils from $10 \mathrm{mM}$ OA-treated fruit than in those from $5 \mathrm{mM}$ OA concentration, without significant differences $(p>0.05)$ among both concentrations of OA on phenolic content (Table 3). This increase on bioactive compounds content was in agreement with results from the 2017 experiment, where OA-treated pomegranate at $10 \mathrm{mM}$ showed a 1.10- and 1.27-fold higher content of total phenolic $(p \leq 0.01)$ and total anthocyanins $(p \leq 0.05)$ than non-treated fruit, respectively (Table 3$)$. With respect to total antioxidant activity (TAA) in the arils, all OA treatments showed a significant increase in a concentration-dependent manner (Table 3). Therefore, $10 \mathrm{mM}$ OA treatment was the most effective at increasing the total antioxidant activity of pomegranate fruit, and this effect was confirmed in the 2017 experiment, although the significant difference was slightly lower in this season $(p<0.05$; Table 3$)$. Significant differences were observed for the bioactive compound content and TAA among years (Table 3).

Table 3. Effects of preharvest oxalic acid (OA) treatments $(1,5$, and $10 \mathrm{mM})$ on bioactive compound concentration, total phenolics and total anthocyanins, and total antioxidant activity (TAA; $\mathrm{g} \mathrm{kg}^{-1}$ ) in the first picking date in 2016 and 2017 experiments. Data are the mean \pm SE.

\begin{tabular}{|c|c|c|c|c|c|}
\hline Parameter & ANOVA $^{+}$ & Control & OA $1 \mathrm{mM}$ & OA $5 \mathrm{mM}$ & OA $10 \mathrm{mM}$ \\
\hline \multicolumn{6}{|c|}{2016 Experiment } \\
\hline Total phenolics & $* * *$ & $0.868 \pm 0.016 \mathrm{aA}$ & $0.852 \pm 0.017 \mathrm{a}$ & $0.958 \pm 0.015 b$ & $0.993 \pm 0.023 \mathrm{bA}$ \\
\hline Total anthocyanins & $* * *$ & $0.136 \pm 0.006 \mathrm{aB}$ & $0.145 \pm 0.006 a$ & $0.168 \pm 0.007 b$ & $0.198 \pm 0.002 \mathrm{cB}$ \\
\hline TAA & $* * *$ & $2.005 \pm 0.059 \mathrm{aB}$ & $2.276 \pm 0.032 b$ & $2.238 \pm 0.030 \mathrm{~b}$ & $2.566 \pm 0.037 \mathrm{cB}$ \\
\hline \multicolumn{6}{|c|}{2017 Experiment } \\
\hline Parameter & $\begin{array}{c}\text { Student } t \\
\text { test }^{*}\end{array}$ & Control & OA $1 \mathrm{mM}$ & OA $5 \mathrm{mM}$ & OA $10 \mathrm{mM}$ \\
\hline Total phenolics & * & $0.846 \pm 0.017 \mathrm{~A}$ & - & - & $0.934 \pm 0.016 \mathrm{~A}$ \\
\hline Total anthocyanins & * & $0.109 \pm 0.004 \mathrm{~A}$ & - & - & $0.138 \pm 0.009 \mathrm{~A}$ \\
\hline TAA & * & $1.750 \pm 0.034 \mathrm{~A}$ & - & - & $1.946 \pm 0.056 \mathrm{~A}$ \\
\hline
\end{tabular}

+ NS $=$ not significant; ${ }^{*},{ }^{* *}$, and ${ }^{* * *}$ significant at $p \leq 0.05,0.01$, and 0.001 , respectively; ${ }^{*}$ values (mean of three replicates) followed by different lowercase letters, within the same row, show significantly differences among treatments, according to the Tukey's multiple range test. ${ }^{¥} \mathrm{NS}=$ not significant; ${ }^{*}$ significant at $p<0.05$, according to the Student's $t$-test. Different capital letters in the same column show significant differences among years for each treatment at $p<0.05$. 


\section{Discussion}

\subsection{Fruit Growth, Crop Yield, and Respiration Rate}

Pomegranate fruit grows continuously from fruit set until the commercial harvest time, enlarging almost to its final size through cell enlargement. During this process, the sepals form a crown, the dry stamen being inside, and the phenological stage of fruit growth lasts around 90 days [28]. The pattern of fruit growth for the Mollar de Elche cultivar shows a simple sigmoid curve, according to previous findings of Shulman et al. [2]. Results showed that OA treatments increased total crop yield due to an increase in the number of fruits that were harvested from each tree, which had a similar mass, independently of the applied concentration. However, in both experiments, treatments were performed when fruit had reached ca $30 \%$ of their final size so that flowering or fruit set were not affected and the increase in fruit number was due to the reduction of fruit abscission that naturally occurs during the fruit developmental cycle due to wind or other environmental factors. In addition, results of the yield on the first harvest date showed that OA treatment hastened the time of harvest in a concentration-dependent manner since the largest number of fruits were harvested in the first harvest, leading also to a greater yield in $\mathrm{kg}_{\mathrm{g}} \mathrm{ree}^{-1}$ than non-treated trees.

An early harvest has important implications for marketing Mollar de Elche pomegranate fruit. Harvesting of Mollar de Elche pomegranate fruit is based on fruit skin coloration, and increase in red skin color will allow early harvest. All OA concentrations used in the trials promoted the on-tree ripening process and improved early maturation and early harvest of this cultivar, $10 \mathrm{mM}$ OA being the most effective. This effect could have important implications for the yield value since the first fruit reaching the market have, in general, higher commercial prices [15]. Supermarket prices represent the upper price segment (premium red pomegranates, large size) that involves indirectly more fruit quality. Consumer prices in markets are significantly lower during the production season, so the early harvest could lead to an increase in the economic profit for the farmer.

As far as we know, no literature is available about the effect of preharvest application of OA on pomegranate crop yield, and contradictory results have been obtained when this preharvest treatment was applied on different plant species. For instance, preharvest foliar application of OA at low concentrations ( 1 and $2 \mathrm{mM}$ ) at the flowering stage in strawberry plants led to an increased number of fruits per plant, $1 \mathrm{mM}$ OA being the best treatment to favor vegetative growth and enhance yield [24]. Similarly, Martínez-Esplá et al. [25] reported that preharvest OA treatment at $2 \mathrm{mM}$ increased crop yield (kg per tree ${ }^{-1}$ ) in "Black Splendor" and "Royal Rosa" plum trees, although the on-tree ripening process was delayed. In addition, an effect of preharvest OA treatment on increasing yield and fruit weight has been found in sweet cherries [20] and plums [25], and was attributed to an increase in net photosynthesis in OA-treated trees and/or to an increase in the sink force of the growing fruit. In this sense, Wang et al. [29] reported that postharvest OA treatment of jujube fruit increased the abundance of RuBisCO activase, $\mathrm{RuBisCO}$ large subunit-binding protein subunit $\beta$, and PSII oxygen-evolving complex protein, which could lead to an increase in photosynthesis rate as a consequence of OA treatment. Contradictorily, Martínez-Esplá et al. [23] reported that 2 mM OA treatment did not affect the on-plant artichoke developmental process or plant yield. According to our results, preharvest treatment with OA could be a good tool to increase crop yield and promote early harvest of pomegranate fruit, which could be related with an effect of OA on increasing the abundance of RuBisco activase enzyme. However, metabolomic studies are needed to fill this knowledge gap.

In non-climacteric fruit, such as pomegranate fruit, a decrease in respiration is normally observed along the tree-developmental cycle [30]. Our results suggest that OA reduced the respiration rate at the time of harvest in comparison to untreated fruit. Similar results have been reported in mango [31] and plum [25]. This effect on decreasing the respiration rate at harvest would indicate an effect of OA on reducing the cell metabolism rate on tree, which, in turn, could be attributed to a lower metabolic activity induced by the treatment. The reduction in respiration rate by OA exogenous application 
may be associated with the corresponding reduction in ethylene production through inhibition of 1-aminocyclopropane-1-carboxylic acid (ACC) synthase activity, according to Razzaq et al. [31].

\subsection{Physico-Chemical Quality Parameters: Color, Firmness, Total Soluble Solids, Titratable Acidity, Ripening} Index, Individual Sugars and Organic Acids, and Sensory Evaluation

Results indicated that the husk red color increased as a consequence of OA treatments. Thus, preharvest OA treatments led to improved external red coloration of pomegranate fruit, which is an important quality trait for this cultivar in terms of market acceptance and early harvest. As we well know, the red color of pomegranate husk and arils are a consequence of anthocyanin biosynthesis and accumulation in the cells and is directly influenced by the amount and composition of anthocyanins presented. Martínez-Esplá et al. [20] reported an increase of color by OA treatments at 0.5, 1.0, and $2.0 \mathrm{mM}$ applied on trees of "Sweet Heart" and "Sweet Late" sweet cherry cultivars. However, in another study, no significant differences were found in skin color hue at harvest between plums treated in preharvest with $2 \mathrm{mM} \mathrm{OA}$ than controls from both picking dates [25]. It has been suggested that $\mathrm{OA}$ promoted the accumulation of phenylpropanoid metabolites including phenolics, flavonoids, and lignins [22,32] through the activation of phenylalanine ammonia-lyase (PAL). However, these findings were not consistent with the report of Zheng et al. [33], where no stimulation of the PAL enzyme was observed by the OA treatment.

On the other hand, fruit firmness is one of the most common physical parameters used to assess the progress of fruit softening and ripening. During fruit ripening, modifications in the cell wall occur due to which fruit loses its firmness. Accordingly, Razzaq et al. [31] showed that higher OA concentration $(0,1,3$, and $5 \mathrm{mM}$ assayed) maintained the highest mango fruit firmness compared to the control fruit during ripening. The higher firmness associated with the treatment may be attributed to the decreased polygalacturonase (PG) and pectin methyl esterase (PME) enzymes activities; that is, the retardation of pectin solubilization/degradation, the reinforcement of the wall structure of mesocarp cells, or the reduction of the hydrolysis of cell wall components during on-tree ripening might have occurred in the OA-treated fruit $[25,34]$.

Skin color, fruit firmness, TSS, and TA are indicators of pomegranate fruit quality [10,35]. Our data indicated that the OA treatment increased TSS content and TA without delaying or promoting the RI of pomegranate fruit at harvest for both seasons. Our physico-chemical data and sensory evaluation proved that pomegranate fruit treated with $\mathrm{OA}$ at $10 \mathrm{mM}$ had appropriate sensory characteristics and higher overall quality than the control fruit, which would lead to better consumer acceptance and improving fruit market potential. Taking into account all these parameters, OA treatment at $10 \mathrm{mM}$ could be a useful tool to improve pomegranate quality traits at harvest. The significant differences observed among years for physico-chemical and functional parameters could be attributed to horticultural practices or climatic conditions $[3,7,8]$, although the differences among treatments were maintained in both years.

The sugar and organic acid profile are in agreement with previous reports on Mollar de Elche and other sweet pomegranate cultivars $[10,11,36]$. On the other hand, exogenous $\mathrm{OA}$ treatment increased endogenous OA content, with $10 \mathrm{mMOA}$ reaching the highest level, according to Wang et al. [29]. In addition, previous reports have found that pre- or postharvest application of OA resulted in fruit with higher ascorbic acid content at harvest and lower losses of this compound during storage [19,24,31,37-39]. OA has been reported as a natural antioxidant by suppressing lipid peroxidation in vitro in a concentration-dependent manner and reducing the ascorbic acid oxidation [40]. However, further investigations need to address the effects of preharvest OA treatment on ascorbic acid metabolism including the de novo biosynthesis, degradation, and recycling to increase ascorbic acid levels in pomegranate fruit during developmental stages and at harvest. 


\subsection{Bioactive Compounds and Total Antioxidant Activity}

As we well know, bioactive compounds have antioxidant properties which are responsible for the beneficial health effects attributed to pomegranate fruit consumption [41]. Our results show that preharvest treatments with $\mathrm{OA}$, especially applied at $10 \mathrm{mM}$, increased the total phenolics and total anthocyanins content, as well as ascorbic acid content, as commented above, leading to increases in the hydrophilic total antioxidant activity (H-TAA). In addition, OA would provide the pomegranate fruit with increased beneficial health effects for human consumption. Previous reports have recently demonstrated that OA treatment enhanced bioactive compounds and increased or preserved antioxidant activity in sweet cherry [18], pomegranate [19], artichoke [23], plum [25], mango [31], muskmelon [32], and grape [42].

The mechanism by which OA increased the bioactive compounds and antioxidant properties is not well understood [31] and deserves further research, although OA has been reported as a natural available antioxidant through suppressing lipid peroxidation in vitro and reducing ascorbic acid oxidation [40]. Results reported by Zhu et al. showed for the first time that preharvest application of OA by spraying on kiwifruit plants increased the postharvest fruit quality and induced fruit disease resistance against $P$. expansum [22]. These effects were attributed to increased activity of defense-related enzymes and resistance-related substance concentrations. In the present study, preharvest OA treatment led to fruit with higher ascorbic acid content at harvest and during postharvest storage, which could reduce patulin production, resulting in a partial degradation of this mycotoxin produced by P. expansum. Similarly, preharvest OA treatment efficiently improved the functional properties of sweet cherries [20]. As a postharvest treatment, results suggested that priming defense responses are involved in the suppressed postharvest decay on muskmelon OA-treated fruit [32] and in pear and mango fruit inoculated with fungal pathogens $[16,33,43,44]$. It was also reported by these authors that the effect of OA treatment reducing decay incidence could be associated with the enhancement of defense-related enzyme activities, accumulation of phenolic compounds, and delay of fruit ripening [16,32,33,43,44]. However, for better understanding of the possible mode of action, molecular, metabolomic, or proteomic studies are needed.

\section{Conclusions}

Preharvest treatments with $\mathrm{OA}$ at 1,5, and $10 \mathrm{mM}$ increased crop yield. In addition, the on-tree fruit ripening process was accelerated in a concentration-dependent manner and $10 \mathrm{mM}$ OA led to the early harvest of Mollar de Elche cultivar, the production and number of fruits being higher in the first harvest date. Among the assayed concentrations, the highest effects were found with $\mathrm{OA}$ at $10 \mathrm{mM}$ which could be selected for practical application purposes in order to get earlier harvest, increase pomegranate crop yield, and improve fruit quality. In addition, $\mathrm{OA}$ application increased the bioactive compound content, which could provide fruit with health beneficial effects to consumers. Moreover, those fruits treated with $\mathrm{OA}$ at $10 \mathrm{mM}$ showed higher sensory quality properties which could promote their marketability in the national and international markets. However, more studies are needed in order to elucidate the effect of OA application on the flowering biology of trees that could affect yield over the year.

Supplementary Materials: The following are available online at http://www.mdpi.com/2073-4395/10/10/1522/s1, Figure S1: Photography data of one replicate ( $\mathrm{n}=5$ fruit) of different treatments; control and oxalic acid $(\mathrm{OA})$ at 1 , 5 and $10 \mathrm{mM}$ concentrations in the 2016 experiment.

Author Contributions: P.J.Z., M.S. and D.V. conceived and designed the work in association with other authors. S.C., J.M.V., F.G. and D.M.-R. performed the field treatments. M.E.G.-P. performed most of the analytical determination in collaboration with M.J.G. Finally, P.J.Z. and D.V. analyzed the data and wrote the manuscript. All authors have read and agreed to the published version of the manuscript.

Funding: This work has been funded by the Spanish Ministry of Economy and Competitiveness through Project AGL2015-63986R and the European Commission with FEDER funds. 
Acknowledgments: The authors thank Miguel Hernández University for Ph.D. scholarship of María E. García-Pastor (grant number 1541/16).

Conflicts of Interest: The authors declare no conflict of interest. The funders had no role in the design of the study; in the collection, analyses, or interpretation of data; in the writing of the manuscript; or in the decision to publish the results.

\section{References}

1. Mir, M.M.; Umar, I.; Mir, S.A.; Rehman, M.U.; Rather, G.H.; Banday, S.A. Quality evaluation of pomegranate crop-A review. Int. J. Agric. Biol. 2012, 14, 658-667.

2. Shulman, Y.; Fainberstein, L.; Lavee, S. Pomegranate fruit development and maturation. J. Hortic. Sci. 1984, 59, 265-274. [CrossRef]

3. Kulkarni, A.P.; Aradhya, S. Chemical changes and antioxidant activity in pomegranate arils during fruit development. Food Chem. 2005, 93, 319-324. [CrossRef]

4. Kader, A.A. Postharvest Biology and Technology of Pomegranates. In Pomegranates. Ancient Roots to Modern Medicine; Seeram, N.P., Schulman, R.N., Heber, D., Eds.; CRC Press-Taylor \& Francis: Boca Raton, FL, USA, 2006; pp. 229-238.

5. Mayuoni-Kirshinbaum, L.; Porat, R. The flavor of pomegranate fruit: A review. J. Sci. Food Agric. 2013, 94, 21-27. [CrossRef] [PubMed]

6. Faria, A.; Calhau, C. The bioactivity of pomegranate: Impact on health and disease. Crit. Rev. Food Sci. Nutr. 2011, 51, 626-634. [CrossRef]

7. Mirdehghan, S.H.; Rahemi, M.; Serrano, M.; Guillén, F.; Martínez-Romero, D.; Valero, D. Prestorage heat treatment to maintain nutritive and functional properties during postharvest cold storage of pomegranate. J. Agric. Food Chem. 2006, 54, 8495-8500. [CrossRef]

8. Özgen, M.; Durgaç, C.; Serce, S.; Kaya, C. Chemical and antioxidant properties of pomegranate cultivars grown in the Mediterranean region of Turkey. Food Chem. 2008, 111, 703-706. [CrossRef]

9. Sreekumar, S.; Sithul, H.; Muraleedharan, P.; Azeez, J.M.; Sreeharshan, S. Pomegranate fruit as a rich source of biologically active compounds. BioMed Res. Int. 2014, 2014, 1-12. [CrossRef]

10. Nuncio-Jáuregui, N.; Calín-Sánchez, Á.; Carbonell-Barrachina, Á.; Hernández, F.; Hernández, F. Changes in quality parameters, proline, antioxidant activity and color of pomegranate (Punica granatum L.) as affected by fruit position within tree, cultivar and ripening stage. Sci. Hortic. 2014, 165, 181-189. [CrossRef]

11. Melgarejo, P.; Salazar, D.M.; Artés, F. Organic acids and sugars composition of harvested pomegranate fruits. Eur. Food Res. Technol. 2000, 211, 185-190. [CrossRef]

12. Fernandes, L.; Pereira, J.A.; Cortés, I.L.; Salazar, D.M.; González-Alvarez, J.; Ramalhosa, E. Physicochemical composition and antioxidant activity of several pomegranate (Punica granatum L.) cultivars grown in Spain. Eur. Food Res. Technol. 2017, 243, 1799-1814. [CrossRef]

13. R (UE) 2016/ 83, 2016. 'Mollar De Elche' Pomegranate (POD). Available online: https://eur-lex.europa.eu/ legal-content/ES/TXT/?uri=CELEX\%3A32016R0083 (accessed on 11 July 2020).

14. Cano-Lamadrid, M.; Lech, K.; Michalska-Ciechanowska, A.; Wasilewska, M.; Figiel, A.; Wojdylo, A.; Carbonell-Barrachina, Á. Influence of osmotic dehydration pre-treatment and combined drying method on physico-chemical and sensory properties of pomegranate arils, cultivar Mollar de Elche. Food Chem. 2017, 232, 306-315. [CrossRef] [PubMed]

15. Laribi, A.; Palou, L.; Intrigliolo, D.; Nortes-Tortosa, P.; Rojas-Argudo, C.; Taberner, V.; Bartual, J.; Pérez-Gago, M.B. Effect of sustained and regulated deficit irrigation on fruit quality of pomegranate cv. 'Mollar de Elche' at harvest and during cold storage. Agric. Water Manag. 2013, 125, 61-70. [CrossRef]

16. Tian, S.; Wan, Y.; Qin, G.; Xu, Y. Induction of defense responses against Alternaria rot by different elicitors in harvested pear fruit. Appl. Microbiol. Biotechnol. 2006, 70, 729-734. [CrossRef] [PubMed]

17. Pareek, S. Novel postharvest treatments of fresh produce. Innov. Postharvest Technol. 2017, 68, 35-51. [CrossRef]

18. Valero, D.; Díaz-Mula, H.M.; Zapata, P.; Castillo, S.; Guillén, F.; Martínez-Romero, D.; Serrano, M. Postharvest treatments with salicylic acid, acetylsalicylic acid or oxalic acid delayed ripening and enhanced bioactive compounds and antioxidant capacity in sweet cherry. J. Agric. Food Chem. 2011, 59, 5483-5489. [CrossRef] [PubMed] 
19. Sayyari, M.; Valero, D.; Babalar, M.; Kalantari, S.; Zapata, P.J.; Serrano, M. Prestorage oxalic acid treatment maintained visual quality, bioactive compounds, and antioxidant potential of pomegranate after long-term storage at $2{ }^{\circ} \mathrm{C}$. J. Agric. Food Chem. 2010, 58, 6804-6808. [CrossRef]

20. Martínez-Esplá, A.; Zapata, P.J.; Valero, D.; García-Viguera, C.; Castillo, S.; Serrano, M. Preharvest application of oxalic acid increased fruit size, bioactive compounds, and antioxidant capacity in sweet cherry cultivars (Prunus avium L.). J. Agric. Food Chem. 2014, 62, 3432-3437. [CrossRef]

21. Razavi, F.; Hajilou, J. Enhancement of postharvest nutritional quality and antioxidant capacity of peach fruits by preharvest oxalic acid treatment. Sci. Hortic. 2016, 200, 95-101. [CrossRef]

22. Zhu, Y.; Yu, J.; Brecht, J.K.; Jiang, T.; Zheng, X. Pre-harvest application of oxalic acid increases quality and resistance to Penicillium expansum in kiwifruit during postharvest storage. Food Chem. 2016, 190, 537-543. [CrossRef]

23. Martínez-Esplá, A.; García-Pastor, M.E.; Zapata, P.J.; Guillén, F.; Serrano, M.; Valero, D.; Gironés-Vilaplana, A. Preharvest application of oxalic acid improves quality and phytochemical content of artichoke (Cynara scolymus L.) at harvest and during storage. Food Chem. 2017, 230, 343-349. [CrossRef]

24. Anwar, R.; Gull, S.; Nafees, M.; Amin, M.; Hussain, Z.; Khan, A.S.; Malik, A.U. Pre-harvest foliar application of oxalic acid improves strawberry plant growth and fruit quality. J. Hortic. Sci. Technol. 2018, 1, 35-41. [CrossRef]

25. Martínez-Esplá, A.; Serrano, M.; Martínez-Romero, D.; Valero, D.; Zapata, P.J. Oxalic acid preharvest treatment increases antioxidant systems and improves plum quality at harvest and during postharvest storage. J. Sci. Food Agric. 2019, 99, 235-243. [CrossRef] [PubMed]

26. Sayyari, M.; Castillo, S.; Valero, D.; Díaz-Mula, H.M.; Serrano, M. Acetyl salicylic acid alleviates chilling injury and maintains nutritive and bioactive compounds and antioxidant activity during postharvest storage of pomegranates. Postharvest Biol. Technol. 2011, 60, 136-142. [CrossRef]

27. García-Pastor, M.E.; Zapata, P.J.; Castillo, S.; Martínez-Romero, D.; Guillén, F.; Valero, D.; Serrano, M. The effects of salicylic acid and its derivatives on increasing pomegranate fruit quality and bioactive compounds at harvest and during storage. Front. Plant Sci. 2020, 11, 668. [CrossRef] [PubMed]

28. Melgarejo, P.; Guillamón, J.M.; Amorós, A.; Martínez-Valero, R. Phenological stages of the pomegranate tree (Punka granatum L.). Ann. Appl. Biol. 1997, 130, 135-140. [CrossRef]

29. Wang, Q.; Lai, T.; Qin, G.; Tian, S. Response of jujube fruits to exogenous oxalic acid treatment based on proteomic analysis. Plant Cell Physiol. 2009, 50, 230-242. [CrossRef]

30. Fonseca, S.C.; Oliveira, F.A.; Brecht, J.K. Modelling respiration rate of fresh fruits and vegetables for modified atmosphere packages: A review. J. Food Eng. 2002, 52, 99-119. [CrossRef]

31. Razzaq, K.; Khan, A.S.; Malik, A.U.; Shahid, M.; Ullah, S. Effect of oxalic acid application on Samar Bahisht Chaunsa mango during ripening and postharvest. LWT Food Sci. Technol. 2015, 63, 152-160. [CrossRef]

32. Deng, J.; Bi, Y.; Zhang, Z.; Xie, D.; Ge, Y.; Li, W.; Wang, J.; Wang, Y. Postharvest oxalic acid treatment induces resistance against pink rot by priming in muskmelon (Cucumis melo L.) fruit. Postharvest Biol. Technol. 2015, 106, 53-61. [CrossRef]

33. Zheng, X.; Ye, L.; Jiang, T.; Jing, G.; Li, J. Limiting the deterioration of mango fruit during storage at room temperature by oxalate treatment. Food Chem. 2012, 130, 279-285. [CrossRef]

34. Wu, F.; Zhang, D.; Zhang, H.; Jiang, G.; Su, X.; Qu, H.; Jiang, Y.; Duan, X. Physiological and biochemical response of harvested plum fruit to oxalic acid during ripening or shelf-life. Food Res. Int. 2011, 44, 1299-1305. [CrossRef]

35. Pareek, S.; Valero, D.; Serrano, M. Postharvest biology and technology of pomegranate. J. Sci. Food Agric. 2015, 95, 2360-2379. [CrossRef] [PubMed]

36. Cano-Lamadrid, M.; Galindo, A.; Collado-González, J.; Rodríguez, P.; Cruz, Z.N.; Legua, P.; Burló, F.; Morales, D.; Carbonell-Barrachina, Á.; Hernández, F. Influence of deficit irrigation and crop load on the yield and fruit quality in Wonderful and Mollar de Elche pomegranates. J. Sci. Food Agric. 2018, 98, 3098-3108. [CrossRef] [PubMed]

37. Liang, C.; Lü, J.; Jin, M.; Li, H.; Rao, J. Effects of oxalic acid treatment on chilling injury, antioxidant capacity and energy status in harvested kiwifruits under low temperature stress. Acta Hortic. Sin. 2017, 44, 279-287. [CrossRef] 
38. Wang, J.; Mao, L.; Li, X.W.; Lv, Z.; Liu, C.; Huang, Y.Y.; Li, D.D. Oxalic acid pretreatment reduces chilling injury in Hami melons (Cucumis melo var. reticulatus Naud.) by regulating enzymes involved in antioxidative pathways. Sci. Hortic. 2018, 241, 201-208. [CrossRef]

39. Ali, M.; Liu, M.M.; Wang, Z.E.; Li, S.E.; Jiang, T.J.; Zheng, X. Pre-harvest spraying of oxalic acid improves postharvest quality associated with increase in ascorbic acid and regulation of ethanol fermentation in kiwifruit cv. Bruno during storage. J. Integr. Agric. 2019, 18, 2514-2520. [CrossRef]

40. Kayashima, T.; Katayama, T. Oxalic acid is available as a natural antioxidant in some systems. Biochim. Biophys. Acta (BBA)-Gen. Subj. 2002, 1573, 1-3. [CrossRef]

41. Panth, N.; Manandhar, B.; Paudel, K.R. Anticancer activity of Punica granatum (Pomegranate): A review. Phytother. Res. 2017, 31, 568-578. [CrossRef]

42. Kok, D.; Bal, E. Changes on bioactive compounds and electrochemical characteristics of cv. Horoz Karası Table Grape ( $V$. vinifera L.) induced by various doses of preharvest applications of benzoic acid, citric acid and oxalic acid at berry setting and verasion periods. Erwerbs-Obstbau 2019, 61, 17-24. [CrossRef]

43. Zheng, X.; Tian, S.; Gidley, M.J.; Yue, H.; Li, B. Effects of exogenous oxalic acid on ripening and decay incidence in mango fruit during storage at room temperature. Postharvest Biol. Technol. 2007, 45, 281-284. [CrossRef]

44. Zheng, X.; Tian, S.; Gidley, M.J.; Yue, H.; Li, B.; Xu, Y.; Zhou, Z.-W. Slowing the deterioration of mango fruit during cold storage by pre-storage application of oxalic acid. J. Hortic. Sci. Biotechnol. 2007, 82, 707-714. [CrossRef]

(C) 2020 by the authors. Licensee MDPI, Basel, Switzerland. This article is an open access article distributed under the terms and conditions of the Creative Commons Attribution (CC BY) license (http://creativecommons.org/licenses/by/4.0/). 